\title{
EVALUATING THE RESPONSE TO FUSARIUM MONILIFORME VAR. SUBGLUTINANS INOCULATION IN PINEAPPLE (ANANAS COMOSUS VAR. COMOSUS) ELICITED BY TWO BIOCONTROLS AND IMPACT ON FRUITLET CORE ROT (BLACK SPOT) DISEASE PROTECTION
}

\author{
${ }^{1 *}$ YEO Navigué Abou, ${ }^{2}$ KONAN Yao Kouakou François, \\ ${ }^{3}$ KOUADIO Oi Kouadio Samuel, ${ }^{4}$ N'goran Kouakou Désiré, \\ ${ }^{4}$ ABEDA Zagadou Herman, ${ }^{4}$ KOUAKOU Tanoh Hilaire, ${ }^{1}$ ZOUZOU Michel \\ ${ }^{1}$ Université Félix Houphouët Boigny, UFR Biosciences, 22 BP 582 Abidjan 22, Côte d'Ivoire \\ ${ }^{2}$ Université Jean Lorougnon Guédé, UFR Agroforesterie, BP 150 Daloa, Côte d'Ivoire \\ ${ }^{3}$ Université Péléforo Gon Coulibaly, UFR Sciences Biologique, BP 1328 Korhogo, Côte d'Ivoire \\ ${ }^{4}$ Université Nangui Abrogoua, UFR Sciences de la Nature, 02 BP 801 Abidjan 02, Côte d'Ivoire \\ *Corresponding Author
}

DOI: https://doi.org/10.51193/IJAER.2021.7506

Received: 05 Oct. 2021 / Accepted: 13 Oct. 2021 / Published: 05 Nov. 2021

\begin{abstract}
The natural defense of pineapple was stimulate to evaluate the tolerance to Fusarium moniliforme var. subglutinans (FMS), agent of fruitlet core rot (FCR). For this purpose, vivoplants of pineapple varieties (MD2 and Smooth Cayenne) were treated with methyl jasmonate (MeJA) and Calliete ${ }^{\circledR}(\mathrm{Ca})$ as well as combination of both biocontrols $(\mathrm{MeJA}+\mathrm{Ca})$. The plants were then inoculated with the pathogen. The incidence of FCR was estimated after inoculation of the flower and opening the fruit at harvest. Protection of pineapple by natural defense stimulators (NDS) against FCR was appraised in fruits of plants treated and inoculated with FMS compared to untreated and inoculated plants. Growth parameters (stem diameter) and physiological parameters such as leaf pigments (chlorophylls and carotenoids) and lignin content were evaluated. The results showed that the elicitors mobilized a wide range of defense molecules in pineapple to undermine the FCR. However, the combination of both elicitors $(\mathrm{MeJA}+\mathrm{Ca})$ has a potentiating effect on the tolerance of pineapple to FMS compared to the
\end{abstract}


elicitors taken individually. The use of natural defense stimulators (NDS) is therefore an effective way to protect pineapple against FMS. Their application in the agricultural environment could contribute to the development of a sustainable agriculture that respects the environment and human health.

Keywords: Pineapple, Fusarium monoliforme, natural defenses stimulator, tolerance, fruitlet core rot disease, Smooth Cayenne, MD2.

\section{INTRODUCTION}

Pineapple plays an important role in the economy, health and food security of populations. It is both an industrial and a food crop. It accounts for $40 \%$ of the world's production of major tropical fruits with exports climbing to 3.1 million tons in 2019 compared to 2018 [1]. However, pineapple is threatened by many pests, parasites and various diseases that contribute to the reduction of production and fruit quality [2]. Fruitlet core rot disease (FCR) is one of the main postharvest disease of pineapple that causes of production loss in pineapple [3]. To control this disease, several strategies were designed to eliminate symptoms. Unfortunately, no control method has been found to be effective so far. These control methods which, by not addressing the cause or the mechanisms of the disease, give only moderate success [4; 5]. In addition, chemical control is increasingly in the spotlight because of the negative consequences on the environment and human health.

In this context, it seems necessary to seek more efficient alternatives for the development of sustainable agriculture. According to Rees and Harborne [6], the ability of a plant species to resist attack by pathogens is most often correlated with the secondary metabolites content such as lignin and leaf pigments that gives a glimpse of plant vitality. Elicitors are generally molecules secreted by microorganisms, derived from the cell wall of the fungus, bacteria and / or the host plant [7]. These molecules have varied modes of action, but instead of mimicking the aggressor, causes a complex cascade of signals, which will lead the plant to induce defense molecules and therefore mobilize its own means of defense [8].

In this study, we focused on host-pathogen interactions through pineapple natural defense systems stimulation in order to increase tolerance to FMS, responsible for fruitlet core rot disease (FCR). First, we performed pathogenicity tests to assess the virulence of the Fusarium moniliforme var. subglutinans (FMS) inoculum on pineapple plants. Second, we described the model of plant elicitation with biocontrols and investigated the plants associated of infection with FMS using two pineapple cultivars (Smooth cayenne and MD-2). Finally, biochemical analyzes of chlorophylls, carotenoids and lignin after inoculation were performed to assess methyl jasmonate and Calliete $₫$ as well as their combination effects on the pineapple protection 
against FCR.

\section{MATERIAL AND METHODS}

\subsection{Plant material}

The plant material used for this study consisted of pineapple shoots of the Smoot Cayenne and MD2 varieties. The suckers of these both varieties, whose mass is between 350 and $500 \mathrm{~g}$, were collected from the farmer's pineapple plantations at Bonoua (Côte d'Ivoire). These cultivars show a very high level of susceptibility to FCR disease caused by FMS.

\subsection{Fungal material}

The fungus Fusarium moniliforme, the causal agent of FCR, was used for inoculations. It was isolated from necrotic areas of pineapple pulp harvested in a plantation at Bonoua, an intensive pineapple production area in Côte d'Ivoire.

\subsection{Experimental design}

The experimental design was consisted of two blocks, A (MD2) and B (Smooth Cayenne), with 5 m apart. Block A was composed of three plots (A, B, C) and block B four plots (A, B, C and D). These plots were spaced $2 \mathrm{~m}$ apart. Each plot contained ridges $6 \mathrm{~m}$ long and $1 \mathrm{~m}$ wide, spaced $1 \mathrm{~m}$ apart. Each ridge consisted of two rows of 10 pineapple plants separated by $50 \mathrm{~cm}$. Experimental plots $(\mathrm{A}, \mathrm{B}, \mathrm{C})$ were made up of 10 ridges and 4 ridges for plot D (Fig 1), where PNTNI is plant not treated with an elicitor and not infected by the fungal strain, PNTI isplant not treated with an elicitor and infected by the fungal strain, PTMI is Methyl jasmonate-treated plant infected with the fungal strain, PTCaI is Calliete-treated plant infected with the fungal strain and PTM+CaI is plant treated with Methyl jasmonate and Calliete combination but uninfected by the fungus.

\subsection{Fungi cultivation}

Fusarium moniliforme strains were isolated from black spots on pineapple fruits showing characteristic symptoms. Under a laminar flow hood, samples collected were placed in Petri dishes containing PDA (Potato Dextrose Agar) medium supplemented with $20 \mathrm{~g} / \mathrm{L}$ potato mash, $20 \mathrm{~g} / \mathrm{L} \mathrm{D}$ - glucose and $20 \mathrm{~g} / \mathrm{L}$ agar. Subculturing of $F$. moniliforme was carried out according to the method described by Vakili[9]. Under a hood, agar fragments of about $0.5 \mathrm{~cm}$ in diameter containing the fungus were taken from the Petri dishes. They were then transferred to a new PDA medium of identical composition to the previous one. The medium was sterilized in autoclave at $120{ }^{\circ} \mathrm{C}$ for $30 \mathrm{~min}$. The inoculated Petri dishes were incubated for 14 days in a culture room at a temperature of $25 \pm 2{ }^{\circ} \mathrm{C}$ under a $12 \mathrm{~h}$ photoperiod. Identification of Fusarium moniliforme was performed according the key of Botton [10] based on macroscopic and microscopic observations. 


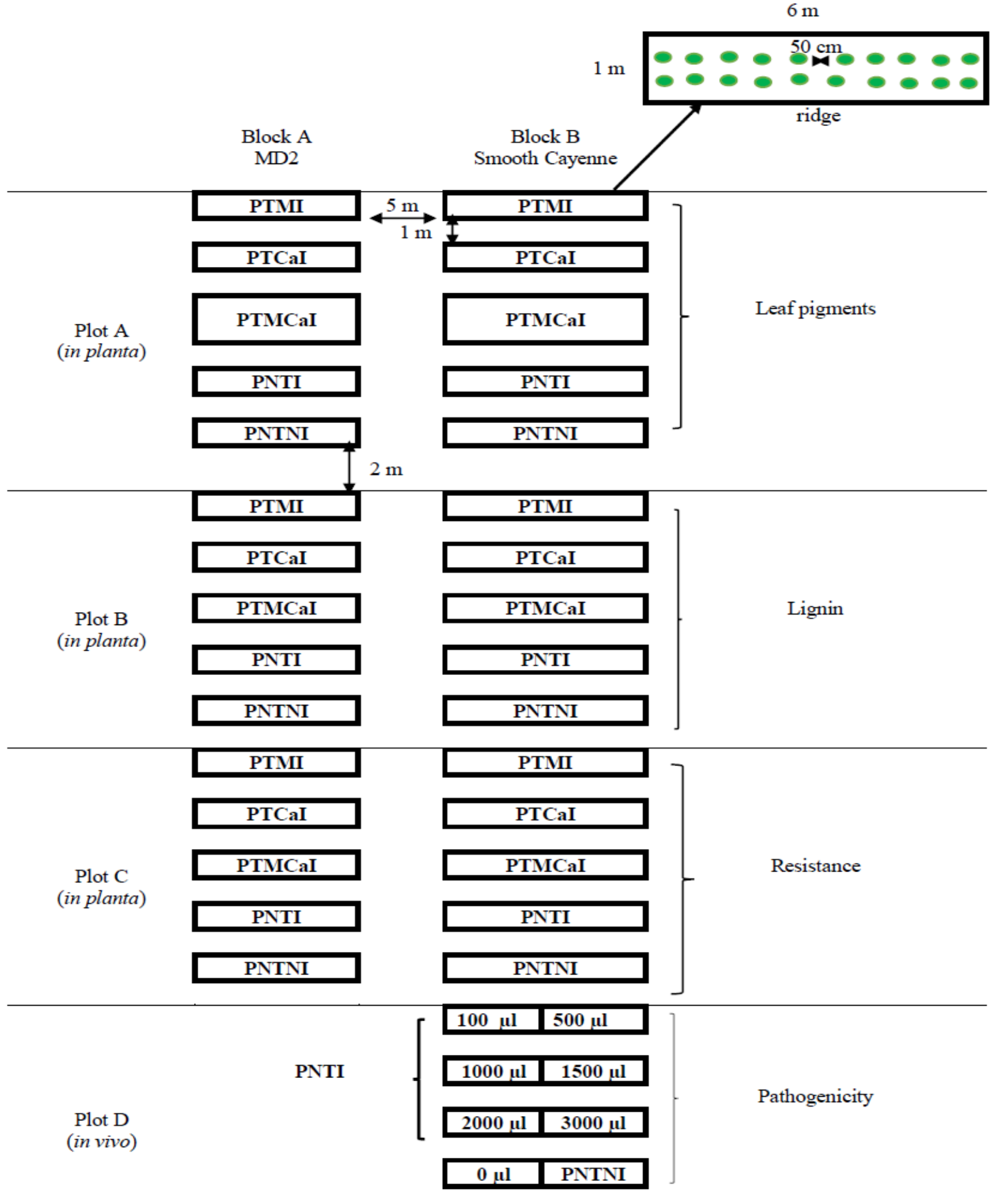

Figure 1: Experimental design 


\subsection{Preparation of pineapple plants for inoculation}

Smooth Cayenne plants were used in this study because this variety was the most sensitive to $F$. moniliforme. The rejects were washed with tap water and disinfected by soaking in a solution containing a mixture of Chlorpyriphos ${ }^{\circledR} 0.03 \%$; Mefenoxan ${ }^{\circledR} 0.02 \%$; Carbosulfan® $0.03 \%$; ethanol $70 \%$ and bleach $2.5 \%$, for $30 \mathrm{~min}$. After rinsing three times with tap water. The seedlings were planted in polyethylene bags containing $3000 \mathrm{~cm}^{3}$ of soil from the experimental site of Nangui Abrogoua University, previously autoclaved at $121^{\circ} \mathrm{C}$ for $45 \mathrm{~min}$. The plants were then kept for 13 months in a greenhouse until the end of the fruiting period, where the light and temperature conditions were close to natural conditions (60 to $70 \%$ humidity, 27 to $28{ }^{\circ} \mathrm{C}$ during the day and 23 to $25^{\circ} \mathrm{C}$ at night). The experiment was triplicate.

\subsection{Preparation of the fungal inoculum}

Agar fragments of 14-day-old $F$. moniliforme were taken from the previous culture medium and ground in the presence of $5 \mathrm{ml}$ of sterile distilled water under a laminar flow hood. The ground material was filtered through sterile gauze which retains the mycelial fragments and allows the spores to pass. About $1 \mathrm{ml}$ of filtrate was placed on each Petri dish containing PDA medium and incubated for seven days under the same conditions as above. Then, the resulting $F$. moniliforme colonies were submerged with $5 \mathrm{ml}$ of sterile distilled water containing a drop of tween 20 . The culture surface was gently scraped with a curved sterile Pasteur pipette to obtain a spore suspension. This method of obtaining the inoculum avoids possible morphological variations. The concentration of the inoculum is determined using a Malassez cell and then adjusted to $10^{4}$ spores $/ \mathrm{ml}$.

\subsection{Fungal inoculation of pineapple plants}

The virulence of $F$. moniliforme was demonstrated by inoculating pineapple plants at the floral stage (after 8 month of planting) of their development cycle, in a greenhouse. Wounds were made on the flowers at eyes level and in the intermediate areas of the eyes, by punctures with a sterile needle connected to a micropipette. To investigate the dose of fungal inoculum having the capacity to induce disease, inoculum volumes of 100, 500, 1000, 1500, 2000 and $3000 \mu \mathrm{l}$ were deposited inside each blooming pineapple flower whose D-leaf have not been treated with biocontrols or elicitors. Plants whose flowers were not inoculated were considered as controls. The symptoms of the disease caused by $F$. moniliforme were monitored by visual observations. The experiment was stopped when the fruits were mature.

The obtained fruits were cut to observe the development of the disease and to estimate the black spot rate. Ten Smooth Cayenne plants were used per inoculum volume and the experiment was 
triplicate.

\subsection{Re-isolation and identification of the fungus}

To confirm the presence and virulence i.e. the pathogenicity of the fungal inoculum isolate, the pineapple plants used for pathogenicity test and which were showed symptoms of the disease, including the control (uninfected), were recovered for a re-isolation of the pathogen. Subculture of necrotic tissues in pineapple pulp was done in Petri dishes on PDA medium as before. After one week of incubation on PDA medium, identification of the fungal strain was performed using the key of Botton et al. [10].

\subsection{Evaluation of the virulence of the fungal inoculum on elicited vivoplants}

\subsubsection{Study of the resistance to Fusarium moniliforme of elicited plants}

The objective of this study was to evaluate in situ the tolerance of pineapple elicited-plants (Smooth Cayenne and MD2) by methyl jasmonate and calliete ${ }^{\circledR}$ to black spot disease, following inoculation with the fungal strain of $F$. moniliforme.

\subsubsection{In situ production of pineapple plants}

Pineapple plants were produced from seedlings of the Smooth Cayenne and MD2 varieties from the Bonoua farmers' plantations. The shoots were first sorted according to size and then trimmed. Surface disinfection was carried out by soaking in a solution containing a mixture of insecticide (Chlorpyriphos ${ }^{\circledR}$ 0.03\%), fungicide (Mefenoxan ${ }^{\circledR} 0.02 \%$ ), bactericide and nematicide (Carbosulfan ${ }^{\circledR} 0.03 \%$ ) for $30 \mathrm{~min}$. After three rinses with sterile distilled water, the rejects were immersed in $70 \%$ ethanol for $5 \mathrm{~min}$ and then in $2.5 \%$ active chlorine bleach for $30 \mathrm{~min}$. After three rinses with distilled water, seedlings were transferred to the experimental plot.

\subsubsection{Elicitation of pineapple plants}

Seven months after cultivation, pineapple D-leaves were sprayed with $50 \mathrm{ml}$ of MeJA (10 $\mathrm{mM} / 72 \mathrm{~h})$, calliete ${ }^{\circledR}(5 \mathrm{mM} / 48 \mathrm{~h})$ and the MeJA/Ca combination (10 mM and $\left.5 \mathrm{mM} / 72 \mathrm{~h}\right)$. The pineapple D-leaves not sprayed with the elicitors were used as controls. For each variety and for each treatment 10 plants were used. This experiment was triplicate.

\subsubsection{Inoculation of pineapple elicited-plants}

After elicitation of pineapple D-leaves, floral induction treatment (FIT) was performed to stimulate flowering. Forty-five days after FIT, flowers were inoculated with $2.5 \mathrm{~mL}$ of $F$. 
moniliforme inoculum at $104 \mathrm{ml} /$ spore. Inoculation was carried out by microinjection into the eyes and/or in the intermediate eye areas using a sterile needle and micropipette. Experiment was triplicate. Five treatments modality groups were constituted:

- plant not treated with an elicitor and not infected by the fungal strain (PNTNI);

- $\quad$ plant not treated with an elicitor and infected by the fungal strain (PNTI);

- Methyl jasmonate-treated plant infected with the fungal strain (PTMI);

- Calliete-treated plant infected with the fungal strain (PTCaI);

- $\quad$ (Methyl jasmonate + Calliete)-traeted plant and uninfected (PTM+CaI).

\subsubsection{Protection of pineapple elicited-plants against fruitlet core rot disease}

To evaluate the effect of exogenous application of elicitors on plants inoculated with Fusarium moniliforme, three parameters were measured. These were the rate of black spots in the fruits, the content of leaf pigments (carotenoids, chlorophyll) and the rate of lignin.

\subsubsection{Fruitlet core rot or Black spot rate in the fruit}

After 12 months of culture, the fruits from treated and non-treated with biocontrols plants were harvested and peeled. Then, a longitudinal section and several horizontal sections of $2 \mathrm{~cm}$ thickness were made. For each of the treatment modalities described above, the number of black spots was counted. Then, the protection of the pineapple after treatment by elicitors was evaluated by the rate of black spots in the fruits according to the following formula:

\subsubsection{Black spot rate in the fruit}

After 12 months of culture, the fruits from treated and non-treated with biocontrols plants were harvested and peeled. Then, a longitudinal section and several horizontal sections of $2 \mathrm{~cm}$ thickness were made. For each of the treatment modalities described above, the number of black spots was counted. Then, the protection of the pineapple after treatment by elicitors was evaluated by the rate of black spots in the fruits according to the following formula:

Black spot rate $=$ [number of contaminated eyes in fruit/number of total eyes in fruit $] \times 100$

Then, the intensity of the disease was estimated through a five-level severity scale:

Degree 0: no black spots in the fruit;

Degree 1: 1-20\% of eyes are spotted in the fruit; 
Degree 2: $20-40 \%$ of eyes are spotted in the fruit;

Degree 3: 40-60\% of eyes are spotted in the fruit;

Degree 4: 60-80\% of eyes are spotted in the fruit;

Degree 5: 80-100\% of eyes are spotted in the fruit.

\subsubsection{Extraction and determination of leaf pigments}

Extraction of chlorophyll pigments and carotenoids was carried out according to the method described by [11], modified and adopted to our plant material. Thus, for each treatment, $200 \mathrm{mg}$ of $\mathrm{D}$ leaves were incubated in the dark, at $4{ }^{\circ} \mathrm{C}$ in a test tube containing $10 \mathrm{~mL}$ of $20 \%$ acetone for $48 \mathrm{~h}$. The whole was ground in the presence of a pinch of calcium carbonate and Fontainebleau and then centrifuged at $5,000 \mathrm{rpm}$ for $15 \mathrm{~min}$ at $4{ }^{\circ} \mathrm{C}$. The supernatant obtained was the crude leaf pigment extract. Untreated and inoculated or uninoculated plants served as a control.

The determination of leaf pigments was carried out according to [12]. The optical density (DO) was measured with a spectrophotometer at $663 \mathrm{~nm}$ and $647 \mathrm{~nm}$ for chlorophyll and $470 \mathrm{~nm}$ for carotenoids, against a control sample made with acetone. The chlorophyll a, b and total content of the leaves $(\mathrm{mg} / \mathrm{g} \mathrm{FM})$ is then calculated using the following formula:

Chlorophyll a $=((12.25 \times$ DO 663) $-(2.79 \times$ DO 647) $x$ V $) / 1000 \mathrm{~m}$

Chlorophyll b $=((21.5 \times$ DO 647) $-(5.1 \times$ DO 663) x V) $/ 1000 \mathrm{~m}$

Total Chlorophyll $=((7.15 \times$ DO 663) $+(18.71 \times$ DO 647) $x$ V $) / 1000 \mathrm{~m}$

Carotenoid $=[(1000 \times$ DO 470 $)-(1.82 \times$ Chl a $-85.02 \times$ Chlb $) / 198) \times$ V $] / 1000 \mathrm{~m}$

Where $\mathrm{m}$ is mass of ground leaf, $\mathrm{V}$ is final volume of extract, FM is fresh matter,Chl is chlorophyll, Car is carotenoids and DO is optical density.

\subsubsection{Extraction and determination of lignin}

The aim was to evaluate the impact of elicitor on lignification in D leaves, stems, roots and flowers. For each treatment modality, ten pineapple plants were used. Samples were collected on day 60 after inoculation with the fungal strain. The experiment was triplicate.

Lignin extraction was performed according to the modified method of Ellis [13]. The collected 
samples were lyophilized and then, ground in a mortar. Then, $10 \mathrm{~g}$ of powder from each sample was weighed and homogenized in an Erlenmeyer flask containing $20 \mathrm{~mL}$ of $96 \%$ ethanol. The mixture was boiled under magnetic stirring for $30 \mathrm{~min}$. The ethanol was drained and replaced with $25 \mathrm{~mL}$ of distilled water. The organic solvent was used to remove simple phenolic acids and polyphenols while the aqueous solvent was used to remove water-soluble compounds such as proteins, tannins and polar molecules. This step was successively repeated twice with ethanol and once with water. The samples were collected, and oven dried for $18 \mathrm{~h}$ at $105^{\circ} \mathrm{C}$.

The assay was also carried out according to the method described by Ellis[13]. Thus, $0.2 \mathrm{~g}$ of powder of each sample was weighed (mass of the test sample) and then homogenized in $5 \mathrm{~mL}$ of $72 \%$ sulfuric acid contained in a crucible previously placed in the oven and weighed after cooling. The mixture was placed on a magnetic stirrer at room temperature for $2 \mathrm{~h}$. After homogenization, $115 \mathrm{~mL}$ of distilled water was added to each crucible to perform hydrolysis with $3 \%$ sulfuric acid. The crucible was then autoclaved at $120^{\circ} \mathrm{C}$ for $1 \mathrm{~h}$ to induce the bursting of the maximum number of cells to release the lignin from the cells. The contents of each crucible were filtered, and the pellet was washed several times with distilled water to remove the cellulose retained in the wood fibers. After washing, the pellet was dried in an oven at $105{ }^{\circ} \mathrm{C}$ for $18 \mathrm{~h}$, then put back into the crucibles and weighed (crucible mass with residue).The lignin content was expressed as a percentage and calculated according to the formula:

Lignin $=[$ Residue mass /Set mass $] \mathrm{x} 100$

where, Residue mass $=$ Crucible mass with residue - Anhydrous crucible mass .

\subsubsection{Statistical analysis}

Statistical analyses were performed using Statistica 7.1 software. An analysis of variance (ANOVA) was performed on all treatments applied. When this analysis showed a difference between the means, Duncan's test was carried out to determine the significant differences between the treatments at the $5 \%$ level. For data in percentages, the Kruskal-Wallis test was used to determine significant differences $(\mathrm{P}<0.05)$ between treatments.

\section{RESULTS}

\subsection{Evaluation of the pathogenicity test of $F$. moniliforme on the Smooth Cayenne plants}

The results of the pathogenicity tests for $F$. moniliforme are given in TABLE1. All the quantities of inoculum used $(0,100,500,1000,1500,2000$ and $3000 \mu \mathrm{l})$ did not induce black spots in the fruit (Fig 2). Indeed, no symptoms were observed in the fruits of plants inoculated with0 and 100 
$\mu 1$ of spore suspension. Symptoms of fruitlet core rot or black spot disease appeared from $500 \mu$ l. Eye discoloration, gum exudation, leaf yellowing and taste alteration were observed from 1500, 2000 and $3000 \mu 1$, respectively. However, the plant became diseased from $1000 \mu 1$ of spores. The doses of 2000 and $3000 \mu 1$ of $F$. moniliforme inoculum were more pathogenic. Black spots were the characteristic symptoms of Fusarium moniliforme manifestation. Control plants showed no symptoms of the disease.

Table 1: Pathogenicity test of Fusarium moniliforme inocula

\begin{tabular}{ccccccc}
\hline $\begin{array}{c}\text { Quantity of } \\
\text { inoculum }(\mathrm{ml})\end{array}$ & $\begin{array}{c}\text { Black } \\
\text { spots in } \\
\text { the fruit }\end{array}$ & $\begin{array}{c}\text { Discoloration } \\
\text { of the eyes }\end{array}$ & $\begin{array}{c}\text { Exudation } \\
\text { of a gum }\end{array}$ & $\begin{array}{c}\text { Yellowing } \\
\text { Of the leaf }\end{array}$ & $\begin{array}{c}\text { Taste } \\
\text { alteration }\end{array}$ & $\begin{array}{c}\text { Plant health } \\
\text { status }\end{array}$ \\
\hline 0 & - & - & - & - & $\mathrm{n}$ & Not sick \\
100 & - & - & - & - & $\mathrm{n}$ & Not sick \\
500 & + & - & - & - & $\mathrm{n}$ & Not sick \\
1000 & ++ & - & - & - & $\mathrm{o}$ & Sick \\
1500 & +++ & + & ++ & - & 0 & Sick \\
2000 & ++++ & ++ & +++ & + & 0 & Sick \\
3000 & +++++ & +++ & & & Sick
\end{tabular}

(-): absence; (+): presence; (n): no; (o): yes;

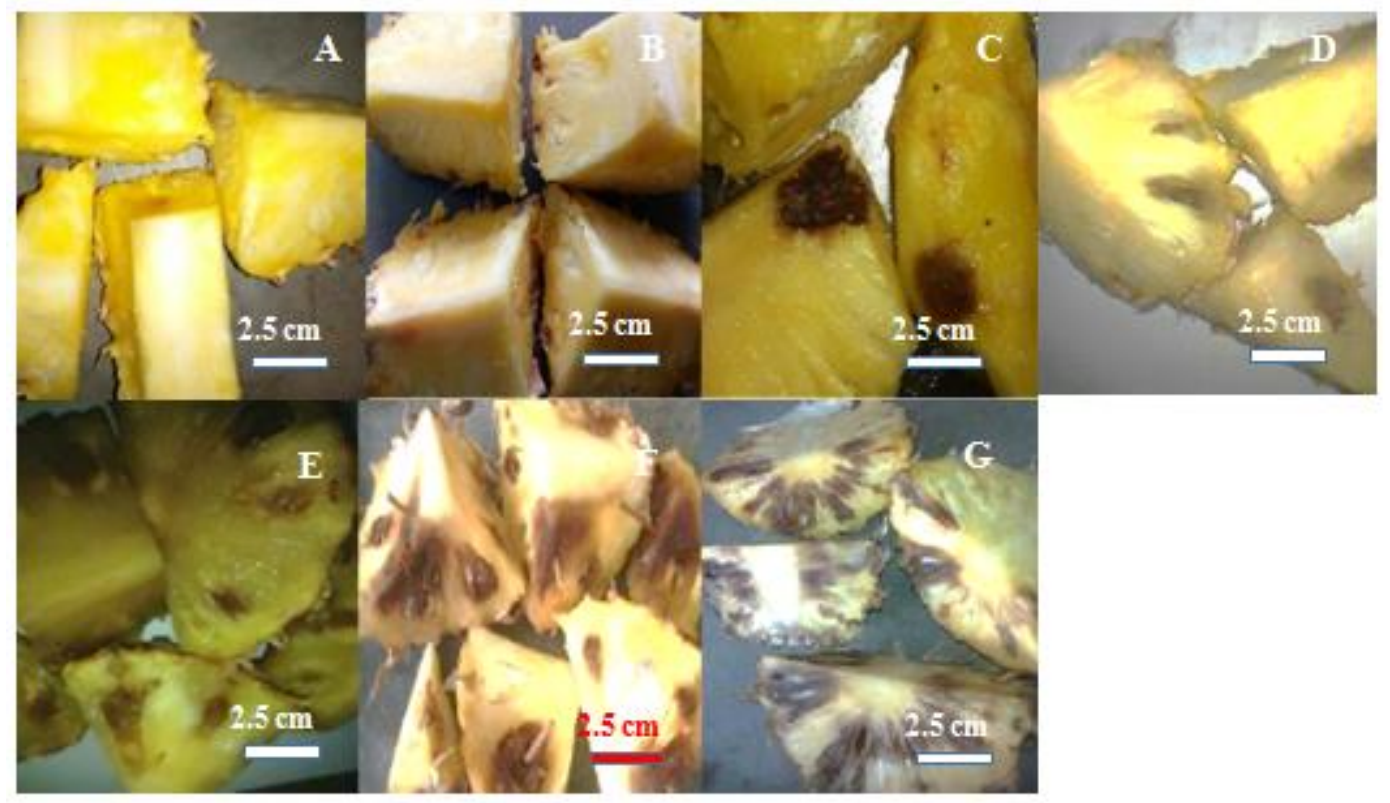

Figure 2: Internal fruit symptoms of Smooth Cayenne at harvest after inoculation with different amounts of Fusarium moniliforme inoculum 
A: control; B: $100 \mu \mathrm{l}$ inoculum; C: $500 \mu \mathrm{l}$ inoculum; D: $1000 \mu \mathrm{l}$ inoculum; E: $1500 \mu \mathrm{l}$ inoculum; F: $2000 \mu \mathrm{l}$ inoculum; G: $3000 \mu \mathrm{l}$ inoculum of $F$. moniliforme

\subsection{Re-isolation and identification of the fungus}

Agar fragments obtained from pineapple black spot tissues (Fig 2) previously cultured on PDA medium were replicated again. After two weeks of incubation, the inoculated tissues developed fungal mycelia on the PDA medium (Fig 3). The result showed a white to peach thallus fungus with dense and flaky aerial mycelium with a powdery appearance. The microconidia are arranged in chains, and are spindle-shaped, unicellular or sometimes uniseptate. Macroconidia are rare, spindle-shaped and septate. There are no chlamydospores (Fig 3). After characterization, the key of Botton et al. [10] identified the isolated fungal strain as Fusarium moniliforme and variety var. subglutinans the causal agent of pineapple fruitlet core rot disease.

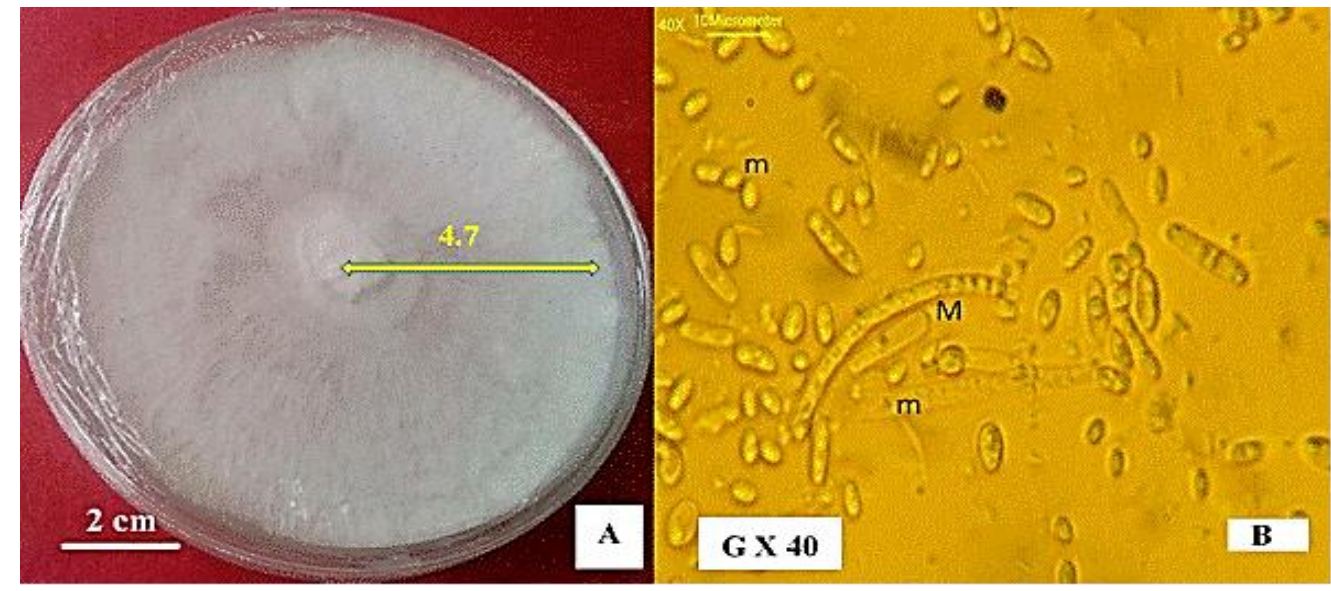

Figure 3: Morphological description of a strain of Fusarium moniliforme extracted from infected pineapple pulp

A: macroscopic appearance; B: microscopic appearance; m: microconidia; M: macroconidia; my: mycelium

\subsection{Evaluation of the severity index or degree of disease in fruit}

The evaluation of the severity or degree of the disease was reported in TABLE 2. The results show that the disease severity index differs according to the type of cultivar (Fig 4). Indeed, untreated and inoculated plants (PNTI) showed the highest levels of contamination, 4 for MD2 against 5 for Cayenne. Untreated and uninfected plants (PNTNI) and those of plants co-treated with MeJA and $\mathrm{Ca}$ (PTMCaI) showed no symptoms of the disease regardless of variety. Plants treated with MeJA and infected (PTMI) had a severity index of level 1 for each cultivar, while those treated with Calliete ${ }^{\circledR}$ and then infected (PTCaI) had a severity index of level 1 for MD2 
International Journal of Agriculture and Environmental Research

ISSN: 2455-6939

Volume: 07, Issue: 05 "September-October 2021"

and a level 2 for Smooth Cayenne.

Table 2: Disease severity index of Fusarium moniliforme

Disease severity index

\begin{tabular}{lccccc}
\hline & PNTNI & PNTI & PTCaI & PTMI & PTM+CaI \\
\hline MD2 & 0 & 4 & 1 & 1 & 0 \\
Smooth Cayenne & 0 & 5 & 2 & 1 & 0 \\
\hline
\end{tabular}

plant not treated with an elicitor and not infected by the fungal strain (PNTNI); plant not treated with an elicitor and infected by the fungal strain (PNTI); Methyl jasmonate-treated plant infected with the fungal strain (PTMI); Calliete-treated plant infected with the fungal strain (PTCaI); plant treated with Methyl jasmonate + Calliete and uninfected $(\mathrm{PTM}+\mathrm{CaI})$.

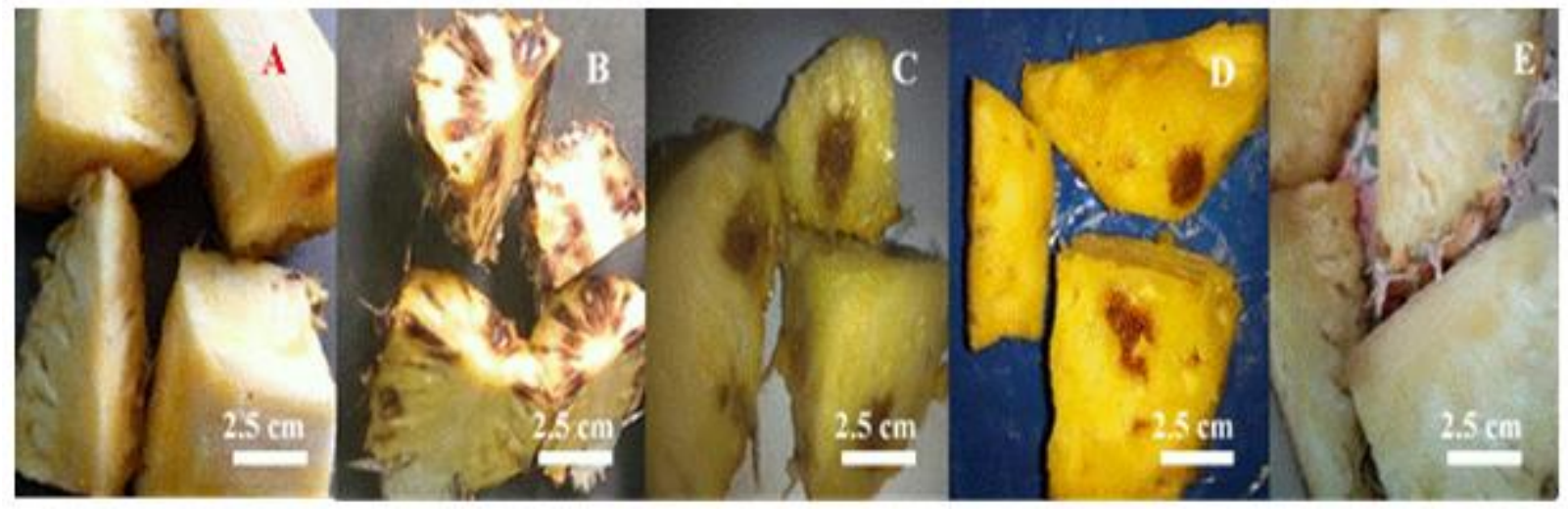

Figure 4: Pulp appearance of Smooth Cayenne pineapple from plants treated with biocontrols and then inoculated with $F$. moniliforme

MeJA: methyl jasmonate; A: untreated and non-inoculated plant; B: untreated and inoculated plant; C: plant treated with calliete ${ }^{\circledR}$ and inoculated; D: plant treated with MeJA and inoculated; E: plant treated with the MeJA and calliete ${ }^{\circledR}$ combination and then inoculated

\subsection{Effect of biocontrols on leaf pigment content of elicited pineapple plants}

The physiological status of the plants was assessed through the content of leaf pigments. Thus, chlorophylls ( $\mathrm{a}, \mathrm{b}$ and total) and carotenoid contents in D-leaves harvested 60 days after fungal inoculation were evaluated. The analysis of the results recorded in TABLE 3, show that the chlorophylls content varies according biocontrols and pineapple variety. Thus, these results reveal that in both varieties (MD2 and Smooth Cayenne), chlorophyll a and total chlorophyll contents increase with the exogenous application of biocontrols compared to the control 
(PNTNI). However, chlorophyll a and total chlorophyll levels were higher in MD-2 than in Smooth Cayenne, regardless of the applied treatment. In these two varieties, the methyl jasmonate (MeJA) and Calliete (Ca) co-treatment (PTM+Ca) induced the highest chlorophyll contents (Chl a andChl total), followed by MeJA (PTMI) and Calliete ${ }^{\circledR}$ (PTCaI) treatment. As for the chlorophyll $\mathrm{b}$ content, the results show that it decreases in the presence of elicitors in MD-2 while it increases in the presence of elicitors in Smooth Cayenne.On the other hand, carotenoid levels showed no significant difference with the application of biocontrols compared to the control (PNTNI: $0.27 \mathrm{mg} / \mathrm{g} \mathrm{FM})$ but PNTI induce a significant decrease $(0.21 \mathrm{mg} / \mathrm{g} \mathrm{FM})$.

Smooth Cayenne variety has evolved in the same direction as the MD-2 variety. Thus, the chlorophyll a and total chlorophyll content is higher in biocontrols-treated and inoculated plants than in untreated and uninoculated plants. Chlorophyll content varied with treatment. However, chlorophyll content was higher in MeJA-treated and inoculated plants (PTMI: $0.69 \mathrm{mg} / \mathrm{g} \mathrm{FM}$ ) than in Calliete ${ }^{\circledR}$-treated and inoculated plants (PTCaI: $0.58 \mathrm{mg} / \mathrm{g} \mathrm{FM}$ ), but their joint effects (PTM+CaI: $0.93 \mathrm{mg} / \mathrm{g} \mathrm{FM})$ increased more than when they were treated alone. No significant difference was observed on chlorophyll b content between PTMI $(0.25 \mathrm{mg} / \mathrm{g} \mathrm{FM})$ and PTCaI $(0.22 \mathrm{mg} / \mathrm{g} \mathrm{FM})$. On the other hand, their additive effects induced the increase of chlorophyll $\mathrm{b}$ content $(0.32 \mathrm{mg} / \mathrm{g}$ FM). Total chlorophyll was higher with the exogenous application of the stimulators especially in PTMI: $0.94 \mathrm{mg} / \mathrm{g}$ MF; PTCaI: $0.81 \mathrm{mg} / \mathrm{g}$ FM; PTM+CaI: $1.25 \mathrm{mg} / \mathrm{g}$ FM compared to the control (PNTNI: $0.61 \mathrm{mg} / \mathrm{g} \mathrm{FM}$ ). The biocontrols do not show a significant effect on the accumulation of carotenoid levels. With PNTI, chlorophyll a, b, total and carotenoids were low amount compared to controls.

\section{Table 3: Effect of exogenous application of elicitors on chlorophyll $a$ and $b$ and carotenoid content of D-leaves of pineapple plants 60 days after inoculation with $F$ usarium moniliforme}

\begin{tabular}{llccccc}
\multicolumn{7}{c}{ Chlorophyll and carotenoid contents (mg/g FM) } \\
\hline Cultivar & \multicolumn{7}{c}{ PNTNI } & PTNI & PTMI & PTCaI & PTM+CaI \\
\hline \multirow{4}{*}{ MD2 } & Chl a & $0.70 \pm 0.02 \mathrm{~d}$ & $0.28 \pm 0.01 \mathrm{e}$ & $0.92 \pm 0.05 \mathrm{~b}$ & $0.83 \pm 0.08 \mathrm{c}$ & $0.98 \pm 0.05 \mathrm{a}$ \\
\cline { 2 - 7 } & Chl b & $0.26 \pm 0.01 \mathrm{~b}$ & $0.40 \pm 0.05 \mathrm{a}$ & $0.20 \pm 0.01 \mathrm{c}$ & $0.18 \pm 0.02 \mathrm{c}$ & $0.11 \pm 0.10 \mathrm{~d}$ \\
\cline { 2 - 7 } & Chl t & $0.96 \pm 0.09 \mathrm{~d}$ & $0.68 \pm 0.07 \mathrm{e}$ & $1.12 \pm 0.05 \mathrm{~b}$ & $1.02 \pm 0.01 \mathrm{c}$ & $1.20 \pm 0.07 \mathrm{a}$ \\
\cline { 2 - 7 } Smooth Cayenne & Car & $0.27 \pm 0.10 \mathrm{a}$ & $0.21 \pm 0.01 \mathrm{~b}$ & $0.29 \pm 0.03 \mathrm{a}$ & $0.28 \pm 0.05 \mathrm{a}$ & $0.28 \pm 0.03 \mathrm{a}$ \\
\hline & Chl a & $0.43 \pm 0.04 \mathrm{~d}$ & $0.05 \pm 0.02 \mathrm{e}$ & $0.69 \pm 0.08 \mathrm{~b}$ & $0.58 \pm 0.16 \mathrm{c}$ & $0.93 \pm 0.08 \mathrm{a}$ \\
\cline { 2 - 7 } & Chl b & $0.17 \pm 0.06 \mathrm{c}$ & $0.10 \pm 0.09 \mathrm{~d}$ & $0.25 \pm 0.01 \mathrm{~b}$ & $0.22 \pm 0.01 \mathrm{~b}$ & $0.32 \pm 0.01 \mathrm{a}$ \\
\cline { 2 - 7 } & Chl t & $0.61 \pm 0.04 \mathrm{~d}$ & $0.15 \pm 0.01 \mathrm{e}$ & $0.94 \pm 0.03 \mathrm{~b}$ & $0.81 \pm 0.05 \mathrm{c}$ & $1.25 \pm 0.04 \mathrm{a}$ \\
\hline & Car & $0.17 \pm 0.02 \mathrm{~b}$ & $0.11 \pm 0.05 \mathrm{~b}$ & $0.19 \pm 0.02 \mathrm{a}$ & $0.17 \pm 0.01 \mathrm{a}$ & $0.20 \pm 0.01 \mathrm{a}$ \\
\hline
\end{tabular}

Values represent the mean of three replicates; $\pm \mathrm{S}$ : standard deviation; within the same line, values followed by the 
sameletter are not significantly different (Newman-Keuls test at 5\%). PNTNI: untreated plants not inoculated with Fusarium moniliforme; PNTI: untreated plants inoculated with $F$. moniliforme; PTMI: plants treated with MeJA and inoculated with $F$. moniliforme; PTCaI: plants treated with calliete ${ }^{\circledR}$ and inoculated with $F$. moniliforme; PTM+CaI: plants treated with Methyl jasmonate + Calliete and uninfected. Chla: chlorophyll a;Chlb: chlorophyll b; Chlt: total chlorophyll; Car: carotenoid; FM: Fresh Mater.

\subsection{Effect of biocontrols on the lignin content of treated pineapple plants}

The results show that treatment of pineapple plants with biocontrols has a positive impact on lignin synthesis in roots, stem, D-leaf and flowers of the cultivars. However, the roots produced the highest levels of lignin regardless of treatment and cultivar followed by the stem, D-leaf and finally the flowers. Moreover, the plants treated with the combination of methyl jasmonate and calliete ${ }^{\circledR}$ and inoculated (PTCa+MI) showed the highest lignin content $(95 \%)$ in Smooth Cayenne and $97.01 \%$ in MD-2 in the roots followed by plants treated with methyl jasmonate and inoculated (PTMI) with a rate of $75.50 \%$ in Smooth Cayenne and81.41 \% in MD-2. On the others hand, plants treated with Calliete ${ }^{\circledR}$ and inoculated (PTCaI) recorded the lowest lignin content $30.50 \%$ in Smooth Cayenne and 36.03 \% in MD-2. As for the untreated and noninoculated plants (PNTNI), the lignin content was $14.30 \%$ in Smooth Cayenne and $15.25 \%$ in MD-2. Untreated and inoculated seedlings (PNTI) induced 7.01 and $08.54 \%$ in Smooth Cayenne and MD-2, respectively (Tab4).

Table 4: Effect of exogenous application of elicitors on lignin content in roots, stem, Dleaves and flower of pineapple plants 60 days after inoculation with Fusarium moniliforme

\begin{tabular}{lcccccc}
\hline \multicolumn{7}{c}{ Chlorophyll and carotenoid contents $(\mathrm{mg} / \mathrm{g}$ FM) } \\
\hline Cultivar & & PNTNI & PTNI & PTMI & PTCaI & PTMCaI \\
\hline \multirow{3}{*}{ MD2 } & Root & $15.25 \pm 0.01 \mathrm{~d}$ & $08.54 \pm 0.08 \mathrm{e}$ & $36.03 \pm 0.02 \mathrm{c}$ & $81.41 \pm 0.04 \mathrm{~b}$ & $97.01 \pm 0.02 \mathrm{a}$ \\
\cline { 2 - 7 } & Stem & $11.32 \pm 0.02 \mathrm{~d}$ & $06.18 \pm 0.01 \mathrm{e}$ & $30.70 \pm 0.03 \mathrm{c}$ & $76.02 \pm 0.01 \mathrm{~b}$ & $86.10 \pm 0.09 \mathrm{a}$ \\
\cline { 2 - 7 } & Sheet & $09.02 \pm 0.04 \mathrm{~d}$ & $03.01 \pm 0.02 \mathrm{e}$ & $24.32 \pm 0.05 \mathrm{c}$ & $55.12 \pm 0.05 \mathrm{~b}$ & $77.20 \pm 0.05 \mathrm{a}$ \\
\cline { 2 - 7 } Smooth Cayenne & Flower & $07.50 \pm 0.02 \mathrm{~d}$ & $02.21 \pm 0.05 \mathrm{e}$ & $20.44 \pm 0.01 \mathrm{c}$ & $38.06 \pm 0.03 \mathrm{~b}$ & $68.04 \pm 0.04 \mathrm{a}$ \\
\hline & Root & $14.30 \pm 0.03 \mathrm{~d}$ & $07.01 \pm 0.07 \mathrm{e}$ & $30.50 \pm 0.08 \mathrm{c}$ & $75.50 \pm 0,06 \mathrm{~b}$ & $95.03 \pm 0.03 \mathrm{a}$ \\
\cline { 2 - 7 } & Stem & $10.45 \pm 0.04 \mathrm{~d}$ & $04.48 \pm 0.06 \mathrm{e}$ & $21.80 \pm 0.01 \mathrm{c}$ & $72.22 \pm 0.08 \mathrm{~b}$ & $83.16 \pm 0.04 \mathrm{a}$ \\
\cline { 2 - 7 } & Sheet & $08.69 \pm 0.08 \mathrm{~d}$ & $02.70 \pm 0.02 \mathrm{e}$ & $20.04 \pm 0.04 \mathrm{c}$ & $30.54 \pm 0.02 \mathrm{~b}$ & $72.01 \pm 0.01 \mathrm{a}$ \\
\cline { 2 - 7 } & Flower & $08.17 \pm 0.01 \mathrm{~d}$ & $02.14 \pm 0.05 \mathrm{e}$ & $10.08 \pm 0.01 \mathrm{c}$ & $21.60 \pm 0.01 \mathrm{~b}$ & $58.60 \pm 0.03 \mathrm{a}$ \\
\hline
\end{tabular}

Values represent the mean of three replicates; \pm S: standard deviation; within the same line, values followed by the same letter are not significantly different (5\% Kruskal-wallis test). MeJA: methyl jasmonate; PNTNI: untreated plants not inoculated with F. moniliforme; PNTI: untreated plants inoculated with F. moniliforme; PTMI: MeJAtreated plants inoculated with $F$. moniliforme; PTCaI: calliet ${ }^{\circledR}$-treated plants inoculated with $F$. moniliforme 
International Journal of Agriculture and Environmental Research

ISSN: $2455-6939$

Volume: 07, Issue: 05 "September-October 2021"

\section{DISCUSSION}

Purification of the fungal isolate revealed the presence of only one morphotype among the progeny. The whitish, cottony appearance of the mycelium and the presence of isolated or chainlike microconidia, macroconidia and the absence of chlamydospores would indicate that the purified fungal isolate is of the Fusarium moniliforme type [14]. The plants used for the pathogenicity test including the control were recovered for re-isolation of the pathogen. Only vivoplants inoculated with the pathogen showed disease symptoms. This result was confirmation of the presence and virulence of the inoculated isolate. Thus, the relationship between the inoculum and the occurrence of black spot disease could be established verifying Koch's postulate [15]. Based on the appearance and color of the developed mycelium, the fungus strain reisolated in the black spot of pineapple pulp showed no morphological variation with that of the parent crop. Microscopic observation revealed that the isolated strain did not exhibit chlamydospores but produced microconidia and macroconidia of the same morphotype as those of the purified strain. In addition, the fact that the fungus isolate was able to cause the disease in inoculated pineapple vitro plants would be evidence that Fusarium moniliforme is indeed responsible for fruitlet core rot or black spot disease [16; 17]. However, subglutinans varietyis the one that is pathogenic for the pineapple in Côte d'Ivoire $[18 ; 19 ; 20]$. Thus, the pathogenic fungus responsible for pineapple fruitlet core rot disease (FCR) in Côte d'Ivoire would be Fusarium moniliforme var. subglutinans.

The severity of the disease induced mainly in pineapple fruits by Fusarium moniliforme var. subglutinans (FMS) was measured on untreated and uninoculated plants (PNTNI), elicitortreated and inoculated plants (PNTI), MeJA-treated and inoculated plants (PTMI), Calliete ${ }^{\circ}$ treated and inoculated plants (PTCaI), and MeJA-treated and Calliete ${ }^{\circledR}$-treated and inoculated plants $(\mathrm{PTM}+\mathrm{CaI})$. Elicitation of the plants showed that these biocontrols promote protection against fruitlet core rot disease caused by $F M S$. Moreover, the low rate of black spot $(\leq 10 \%)$, suggests that MeJA-treated pineapples can be considered $90 \%$ tolerant to the pathogenic form of FMSfor both varieties (MD-2 and Smooth Cayenne) while those treated with Calliete ${ }^{\circledR}$ were considered $78 \%$ resistant to the pathogen for the Smooth Cayenne cultivar and $85 \%$ for MD-2. Indeed, the pathogenicity test of a fungal isolate is valid when the black spot rate of the plants exceeds $20 \%$ [21]. Our results are similar to those reported by Belhadj et al. [22]on resistance to Erysiphe necator, the causal agent of powdery mildew in grapevine. These authors showed that plants treated with MeJA developed increased resistance against the disease. In addition, Konan et al. [23] reported induced disease resistance to Fusarium oxysporum in cotton treated with MeJA.

Then, Natali [24] also showed the role of Calliete ${ }^{\circledR}$ against Phytophtora, the downy mildew 
International Journal of Agriculture and Environmental Research

ISSN: 2455-6939

Volume: 07, Issue: 05 "September-October 2021"

disease in pineapple. Thus, the treatment with stimulators allowed a considerable reduction of the intensity of the fungal attack and an effective resistance against the pathogens. Plants cotreated with MeJA and Calliete ${ }^{\circledR}$ did not show black spots in the fruits. This suggests $100 \%$ resistance to FMS. This treatment was therefore effective against FMS-induced FCR in pineapple. The co-treatment seems to provide a complementary effect by increasing the efficacy of MeJA applied alone. Indeed, the action of MeJA would be enhanced by co-treatment with Calliete ${ }^{\circledR}$ via ethephon (ethylen) as already reported by several stidies $[25 ; 26 ; 27]$. According to Natali[24], fosethl-aluminium, the active molecule of Calliete ${ }^{\circledR}$, induces the production of defense molecules by ethylene pathway. Thus, ethylene in the form of ethephon improved the increase in tolerance to FMSinduced by methyl jasmonate in pineapple. The role of co-treatment of MeJA and Calliete ${ }^{\circledR}$ via ethephon in plant defense had already been reported in many plants as activator, inducer and accumulator of phytoalexins and PR proteins. Similary, protective effect of biocontrol against pathogens has already been demonstrated in several plants $[28 ; 27$; $29 ; 30]$.

Furthermore, under the action of FMS, it was observed in both cultivars a degradation of leaf pigments (Chlorophyll a, carotenoids and total Chlorophyll) with the exception of Chlorophyll b, which increased in cultivar MD-2. However, MeJA application induces an increase in Chlorophyll a and total chlorophyll. The increase in total chlorophyll content was only due to chlorophyll a. Indeed, MeJA, would induce a bioconversion of Chlorophyll b into Chlorophyll a thus increasing the content of D-leaves in Chlorophyll a and thus a good photosynthetic activity [31; 32].Application of biocontrols in pineapple has a beneficial action on the synthesis of secondary metabolites such as Chlorophyll a. It is a good indicator of the vitality or vigor of the plants. Indeed, chlorophyll a is the main photosynthetic pigment. It allows the conversion of light energy into chemical energy (in the form of ATP) while the other pigments (chlorophyll (b) and carotenoids that transmit energy to it by resonance are called accessory pigments $[33 ; 34 ; 35]$. Moreover, Couderchet et al. [36] reported a close relationship between PR proteins, induced phytoalexins and protoporphyrogen oxidase, an enzyme involved in chlorophyll synthesis. Yet, MeJA has been shown to stimulate the production of phenolic compounds as well as PR proteins [37;38; 39]. This could also explain the significant increase in chlorophyll a contents observed in MeJA- and Calliete-elicited susceptible seedlings compared to non-elicited ones. This result suggests that the increase in chlorophyll caused good photosynthetic activity in MeJA and Calliete ${ }^{\circledR}$ treated plants. Thus, the induction of the antifungal molecules PR proteins and phytoalexins, correlated with the increase in chlorophyll a levels under the action of MeJA and Calliete ${ }^{\circledR}$ seems to be the basis for the good physiological condition and tolerance of pineapple plants.

The decrease in chlorophyll (Chl a and Chl total) content in the PNTI showed that the inoculated 
International Journal of Agriculture and Environmental Research

ISSN: 2455-6939

Volume: 07, Issue: 05 "September-October 2021"

fungal strain destroys or degrades these chlorophylls. Indeed, the plant needs sugars to ensure its growth, its development and the implementation of defense mechanisms. Sugars are synthesized in the leaves and then transported via the stem to the plant's sink organs (roots, flowers, leaves, fruits). For its part, the fungus, which is heterotrophic for carbon, draws sugars from the tissues it infects. There is therefore competition for carbon resources. The pathogen can then represent a new sink that will divert assimilate flows within the plant to its own benefit. In this competition between the plant and the fungus, the mobilization of sugars is a major issue for both adversaries, the pineapple plant trying to defend itself and the fungus to develop [40;23]. The plant will not be able to feed properly, loses its vigor and becomes susceptible to attack. In addition, Fusarium moniliforme blocks the activation of magnesium chelatase and chlorophyllase, enzymes involved in chlorophyll biosynthesis [41].As for carotenoids, the content does not change between plants treated and plants not treated with elicitors. This could be explained by the fact that photosynthesis does not depend on the carotenoid content [42].

The evaluation of the effect of biocontrols on the reinforcement of the cell walls of plants inoculated with $F$. moniliforme through the quantification of lignins in roots, stems and leaves on the $60^{\text {th }}$ day after fungus inoculation, showed an increase in their level in treated and inoculated plants compared to controls. These results suggest that lignins are essential constituents of any xylem vessels because they are the basis of the rigidity of organs $[43 ; 23 ; 35]$. in fact, it is deposited in the wall of plant cells, preventing the pathogen from entering the cell. Lignin participates in the formation of the first barriers against the invasion of pathogens into the cell to induce disease. Thus, a high level of lignins would reduce the chances of a pathogen to penetrate a plant [13]. To this effect, the work of some researchers reported that the strategy implemented by the plant in case of attack against any biotic or abiotic aggressor as soon as possible and which is common to all plants is the reinforcement of the cell wall [8]. This technique aims to prevent the entry of the aggressor into the cells by thickening the wall at the site of pathogen penetration. Kauffmann et al. [44] also approved that the plant synthesizes several molecules such as proteins, polysaccharides or aromatic polymers to reinforce the wall after an infection. Moreover, many authors have shown that these modifications occur at several levels and involve several substances that vary from plant to plant $[45 ; 46]$. Lignin content was correlated with the frequency of pathogen infection [47]. Lignin participates in plant defense mechanisms by making the cell wall rigid and impermeable, and protecting plants from microbial invasion [48]. Studies have proven the involvement of biocontrols including MeJA in lignin biosynthesis [49; $50 ; 51]$.

Furthermore, results also showed high levels of lignins in roots, followed by stems, leaves and flowers in all treatments. Roots are the first organs to come into contact with Fusarium moniliforme var. subglutinans (FMS) because itsurvives well on plant debris deposited on the 
International Journal of Agriculture and Environmental Research

ISSN: $2455-6939$

Volume: 07, Issue: 05 "September-October 2021"

soil surface or slightly buried $[52 ; 53]$. Thus, a high lignin content in the roots will strengthen the cell walls and slow the penetration of the fungus into the plant. In this case, being heterotrophic, FMS becomes a parasite of the aerial parts and was dispersed by wind and insects [2]. Thus, the application of elicitors would be beneficial to the plant in order to carry out a generalized counter-attack. The results also showed a low lignin content in the PNTI. This shows that the presence of the fungus in the plant negatively influences the production and metabolism of lignins. Indeed, Hückelhoven [54] reported that blocking lignin biosynthesis enzymes with inhibitors decreased lignin content and favored pathogen penetration. Therefore, the increase in lignin level that acts as a physical barrier in the plant due to exogenous application of biocontrol on pineapple D-leaves would be necessary. The MeJA and Calliete ${ }^{\circledR}$ (ethephon) co-treatment or separately made it possible to increase the level synthesis of lignin in all the organs of the plant conferring complete tolerance to FMS [45; 13; 27].

\section{CONCLUSION}

The pathogenicity of Fusarium moniliforme var. subglutinans (FMS) on pineapple plants confirms the ability of biocontrols to induce natural defense mechanisms. In fact, the biocontrol treatment induced tolerance to FMS. However, the combination treatment of MeJA and Calliete ${ }^{\circledR}$ resulted in greater protection against FMS, the causative agent of fruitlet core rot disease or black spot disease in pineapple. Thus, there was a gain in resistance, which was distinguished by a total disappearance of the parasite pressure. This protection of pineapple through biocontrols was also manifested by a strengthening of the cell walls by an increasingly high lignification at the level of roots, stems, leaves and flowers. This treatment also stimulates photosynthetic activity for vigor plant growth and may therefore be a significant and promising alternative to chemical control of FMS. Its introduction in agricultural practices can contribute to the development of sustainable agriculture.

\section{REFERENCES}

[1] FAO (2019). Food and Agriculture Organization of the United Nations. Major tropical fruits- market analysis http://www.fao.org/economic/est/est-commodities/fruitstropicaux/fr/

[2] Py, C., Lacoeuilhe, J. J\& Teisson, C (1984). Pineapple, its culture and products. Agricultural techniques and tropical productions. p $238-240$.

[3] Onuorah, S.C., Udemezue, O.I., Uche, J.C. \& Okoli, I.C (2013). Fungi Associated with the Spoilage of Pineapple Fruits in Eke Awka Market Anambra State. The Bioscientist, 1: 22-27.

[4] Cabot, C., Pinon, A., Bouffin, J., Teisson, C., Soler, A., Combres, J.C., Penel J.P., Kehe 
International Journal of Agriculture and Environmental Research

ISSN: 2455-6939

Volume: 07, Issue: 05 "September-October 2021"

M., Frossard P. \& Mourichon X (1984). Export pineapple cultivation in Côte d'Ivoire. Manuel du plantteur. IRFA (Institut de Recherche sur les Fruits et Agrumes). Nouvelles Editions Africaines - Abidjan. 112 p.

[5] Barral, B., Chillet, M., Léchaudel., Lartaud, M., Verdeil, J.L., Conéjéro, G. \& SchorrGalindo, S (2019). An imaging approach to identify mechanisms of resistance to pineapple fruitlet core rot. Frontiers in Plant Science, 10: 1-12.

[6] Ress, S.R. \& Harbone E.B (1985). The role of sesquiterpene lactones and phenolics in the chemical defence of the chicory plant. Phytochemistry,24 (10): 2225-2231.

[7] Korsangruang, S., Soonthornchareonnon, N., Chintapakorn, Y., Saralamp, P.\& Prathanturarug, S (2010). Effects of abiotic and biotic elicitors on growth and isoflavonoid accumulation in Pueraria candollei var. candollei and P. candollei var. mirifica cell suspension cultures. Plant Cell, Tissue and Organ Culture, 103: 333-342.

[8] Belhadj, A., Saigne, C., Telef, N., Cluzet, S., Bouscaut, J., Corio-Costet, M. F \& Mérillon J.M (2006). Methyl jasmonate induces defense responses in grapevine and triggers protection against Erysiphenecator.Journal of Agricultural and Food Chemistry, 54 (24): 9119 - 9125.

[9] Vakili,N.G (1968). Response of Musa acuminata species and edible cultivars to infection by Mycosphaerrella musicola. Tropical Agriculture, 45: 13-22.

[10] Botton, B., Breton, A., Fevre, M., Gauthier, S., Guy, P.H., Larpent ,J.P., Reymond, P., Sanglier, J.J., Vaysier, Y. \& Veau, P. (1990).Moisissures utiles et nuisibles importances industrielles. In: Jean Paul Larpent (Ed.), Biotechnologies. Masson. 494 p.

[11] Lichtenthaler, H.K (1987). Chlorophylls and Carotenoids: Pigments of Photosynthetic Biomembranes. Methods in Enzymology, 148, 350-382.

[12] Harborne (1984). PhytochemicalsMethods, A GuidetoModern Techniques ofPlant Analysis. $2^{\text {nd }}$ edition. Chapmanand Hall. USA.

[13] Ellis, G.H., Matrone, G.\& Maynard, L.A (2006). A 72 per cent sulfuric acid method for the determination of lignin and its use in animal nutrition. Journal Animal Sciences, 5: $285-297$.

[14] Botton, R., Breton, A., Fevre, M., Guy, P.H., Larpent, J.P., \& Veau P (1985). Useful and harmful moulds. Industrial importance. Biotechnologies. Masson, pp 139 - 145.

[15] Breitschwerdt, E.B., Linder, K.L., Day, M.J, Maggi, R.G., Chomel, B.B. \& Kempf, V.A.J. (2013). Koch's postulates and the pathogenesis of comparative infectious disease causation associated with Bartonella species. Journal of Comparative Pathology 148(2): 115-125.

[16] Perriot (1980). Pathology and characteristics of various races and special forms within the species Fusarium moniliforme var. subglutinans Fruits, 35 (6): 335-354.

[17] Laville (1980). Fusarium head blight of pineapple, synthesis of present knowledge 
(IRFA). Fruits, 35 (2): 101- 113.

[18] Dianese, J.C., Bolkan, H.A., Da Silva, C.B.\& Couto, F.A.A (1981). Pathogenicity of Epiphytic Fusarium moniliforme var. subglutinans to Pineapple. Phytopathology 71(11):1145-1149.

[19] de Matos, A.P.\& Mourichon, X (1993). Development of resistance to infection by Fusarium moniliforme var. subglutinans in wounds of pineapple plantlets. Acta Horticulturae, 334: 423-428.

[20] Misra, A.K.\& Si, V.K (2002). Fusarium subglutinans (= F.moniliforme var. subglutinansi in relation to mango malformation. Indian J. Plant Pathol. 20 (1-2) : 81-33

[21] Djerbi, M. (1990). Caracterization of Fusarium oxysporum f.sp. albedinis the causal agent ofbayoud disease on the basis of vegetative compatibility. Procceding of eight congress of theMeriterranean Phytopathological union, Agadir, Morocco, 513p.

[22] Belhadj, A., Telef, N., Saigne, C., Cluzet, S., Barrieu, F., \& Hamdi S (2008). Effect of methyl jasmonate in combination with carbohydrates on gene expression of PR proteins, stilbene and anthocyanin accumulation in grapevine cell cultures. Plant Physiology and Biochemistry, 46 (4): 493-499.

[23] Konan, Y.K.F., Kouassi, K.M., Kouakou, K.L., Koffi, E., Kouassi, K.N., Sékou D., Koné, M. \& Kouakou, T.H (2014). Effect of Methyl jasmonate on phytoalexins biosynthesis and induced disease resistance to Fusarium oxysporum f. sp. vasinfectum in Cotton (Gossypium hirsutum L.). International Journal of Agronomy 2014: 1 - 11.

[24] Natali, A (2008). Efficacité des phosphanates contre les maladies cryptogamiques. Agriclean ed., 9p.

[25] Farmer, E.E., Alméras, E., \& Krishnamurthy, V (2003). Jasmonates and related oxylipins in plant responses to pathogenesis and herbivory. Current Opinion Plant Biological, 6: $372-378$.

[26] Tamaoki, M., Freeman, J.L., \& Pilon-Smits, E.A (2008). Cooperative ethylene and jasmonic acid signaling regulates selenite resistance in arabidopsis. Plant Physiology, 146 (3) : 1219-30.

[27] Faurie, B., Cluzert, S., Corio-Costet, M.F.\& Merillon, J.M (2009). Methyl jasmonate/ethephon cotreatment synergistically induce stilbene production in Vitis vinifera cell suspensions but fails to trigger resistance to Erysiphe necator. Journal Interface Science, 43 (2): 99 - 110.

[28] Larronde, F., Gaudillière, J.P., Krisa, S., Decendit, A., Deffieux, G., \& Mérillon, J.M (2003). Airborne methyl jasmonate induces stibene accumulation in leaves and berries of grapevine plants. American Journal of Enology and Viticulture, 54 (1): 60 - 63.

[29] Lecomte, M (2013). Analysis of the defense mechanisms of carrot (Daucus carota) against the pathogenic fungus. Alternaria dauci, responsible for alternaria or leaf blight. 
International Journal of Agriculture and Environmental Research

ISSN: 2455-6939

Volume: 07, Issue: 05 "September-October 2021"

$\mathrm{PhD}$ thesis from the University of Angers, France, $155 \mathrm{p}$.

[30] Samuel, K.O.K., Mohamed, D., Oumar, S., N'guessan Kan, P.K. \& Tanoh, H.K (2021).Stimulation of Polyphenol Production by Three Biocontrols (Vacciplant ${ }^{\circledR}$, Callel $®$, and Calliete ${ }^{\circledR}$ ) in Plantain (Musa spp. Group AAB [Musaceae]). Journal of Agricultural Science, 13 (9): 135-147.

[31] Folly, P (2000). Catabolism of chlorophyll b Structures, mechanisms and synthesis. PhD. thesis from the University of Fribourg, Switzerland 192 p.

[32] Djapic, N (2012). Chlorophyll catabolism in Prunus serrulata autumnal leaves. Facta Universitatis Series: Physics, Chemistry and Technology, 10 (1): 21 - 26.

[33] Olson, J.M (2006). Photosynthesis in the Archean Era. Photosynthesis Research, 88 (2): $109-117$.

[34] Raven, H., Evert, R.F.\& Eichhorn, S.E (2007). Plant Physiology ${ }^{2 n d}$ edition, coll. "Editions De Boeck Université", Brussels, Belgium, 121 p.

[35] N'cho (2018). Elicitation of banana by methyl jasmonate and salicylic acid: impact on phenolic compounds, efficacy on Mycosphaerella fijiensis causing black stripe disease. Doctoral thesis. Université Nangui Abrogoua, Abidjan, Côte d'Ivoire 198 p.

[36] Couderchet, M., Le Floch, G., Rey P.\& Tirilly Y (2003). Effect of flumioxazine on Botrytis cinerea attack on tomato leaves. In AFPP, ed: 7th International Conference on Plant Diseases, Tours, France, 58 p.

[37] Otalvaro, F., Nanclares, J., Vasquez, L.E., Quinones, W., Echeverri, F., Anango, R.\& Schneider B (2007). Phenalenone-type compounds from Musa acuminata var. Yangambi km 5" (AAA) and their activity against Mycosphaerella fijiensis. Journal of Natural Products 70: 887 - 890.

[38] Jain, S., \& Kumar, A (2015). The pathogenesis related class 10 proteins in plant defense against biotic and abiotic stresses. Advances in Plants and Agriculture Research, 3 (1): 1 $-11$.

[39] Hidalgo, W., Chandran, N.J., Menezes, R.C., Otalvaro, F., \& Schneider B (2016). Phenylphenalenones protect banana plants from infection by Mycosphaerella fijiensis and are deactivated by metabolic conversion. Plant Cell and Environment, 39: 492 - 513.

[40] Afoufa-Bastien, D., Medici, A., Jeauffre, J., Coutos-Thevenot, P., Lemoine, R., Atanassova, R.\& Laloi M (2010). The Vitis vinifera sugar transporter gene family: phylogenetic overview and macroarray expression profiling. BMC Plant Biology, 10: 245 - 267.

[41] Djapic, N., Djuric, A., \& Pavlovic, A (2009). Chlorophyll biodegradation in Vitis vinifera var. Pinot noir autumnal leaves. Research Journal of Agriculture Science, 41 (2) : 256 26.

[42] Zarco-Tejada, P. J., Miller, J. R., Mohammed, G. H., Noland, T.L., \& Sampson P. H 
International Journal of Agriculture and Environmental Research

ISSN: 2455-6939

Volume: 07, Issue: 05 "September-October 2021"

(2002). Vegetation stress detection through chlorophyll $\mathrm{a}+\mathrm{b}$ estimation and fluorescence effects on hyperspectral imagery. Journal of Environmental Quality, 31: 1433 - 1441.

[43] Zhu, Z., \&Tian, S (2012). Resistant responses of tomato fruit treated with exogenous methyl jasmonate to Botrytis cinerea infection. Scientia Horticulturae, 142: 38-43.

[44] Kauffmann, S., Dorey, S. \& Fritig, B (2001). Defense strategies. Pour la Science, pp 16121.

[45] Hammond-Kosack, K.E., \& Jones, J.D.G (1996). Resistance gene-dependent plant defense responses. Plant Cell, 8: 1773 - 1791.

[46] Kauss, H., Franke, R., Krause, K., Conrath, U., Jeblick, W., Grimming, B. \& Matern, U (1993). Conditioning of parsley (Petroselinum crispum L.) suspension cells increases elicitorinduced incorporation of cell wall phenolics. Plant Physiology, 10: 459 - 466.

[47] Myoung-Hoon, L., Hwi, S.J., Seu, H., Joo, H.C., Daniele, R., Hye-Jung, L., Hong, J.C., Yuki, T., John, R.\& Ohkmae, K.P(2019). Lignin-based barrier restricts pathogens to the infection site and confers resistance in plants. European Molecular Biology Organization Journal 8(23):1-17.

[48] Van Parijs, K. Moreel, J. Ralph, W. Boerjan. \& Merks, R.M.H (2010).Modeling lignin polymerization. I. Simulation model of dehydrogenation polymers. Plant Physiology, 153:1332-1344.

[49] Oliveira, M.B, Juniorb, M.L, Grossi-de-Sác, M.F. \&Petrofeza, S (2015). Exogenous application of methyl jasmonate induces a defense response and resistance against Sclerotinia sclerotiorum in dry bean plants. Journal of Plant Physiology 182, 1322.

[50] Chakraborty, N., \& Basak, J (2018). Exogenous application of methyl jasmonate induces defense response and develops tolerance against mungbean yellow mosaic India virus in Vigna mungo. Functional Plant Biology 46(1): 69-81.

[51] N'goran (2019). Regulation of polyphenol biosynthesis by fungal oligosaccharide and mycelial elicitors, effect on tolerance of cotton (Gossypium hirsutum L.) to Fusarium head blight. PhD thesis. Université Nangui Abrogoua, Abidjan, Côte d'Ivoire 197 p.

[52] Matos, A.P., \& Souto G. F (1985). Reaction of pineapple, cultivars perola and smooth cayenne, to inoculation with Fusarium monoliforme sheld. var. subglutinans. Fruits, 40: $641-645$.

[53] Matos, A.P (1987). Pineapple fusariosis in Brazil: an overview. Fruits, 42: 417-422.

[54] Hückelhoven, R. (2007). Cell wallassociated mechanisms of disease resistance and susce ptibility.Annual Revue Phytopathology, 45:101-127. 